\title{
Technical Potential of Biogas Technology Adoption in Replacing Firewood, Kerosene and Chemical Fertilizer: The Case of Misrak and Mirab Estie Districts, in Northern Ethiopia
}

\section{Haile Fentie}

Hawassa Umiversity, Department of Biology

Getachew Sime ( $\sim$ abigiag@yahoo.com )

Department of Biology, College of Natural Sciences, Hawassa University, Hawassa, Ethiopia https://orcid.org/0000-0002-4406-3770

Original article

Keywords: Bio-slurry, biogas, firewood, household, Ethiopia

Posted Date: September 22nd, 2020

DOI: https://doi.org/10.21203/rs.3.rs-66861/v1

License: (9) This work is licensed under a Creative Commons Attribution 4.0 International License.

Read Full License 


\section{Abstract}

Background: The depletion of bioenergy sources has caused significant deforestation, low agricultural production and energy crisis. This study evaluates the technical potential of biogas technology adoption in replacing firewood, charcoal, kerosene and chemical fertilizer in Northern Ethiopia.

Methods: Questionnaire household survey, key informant interview, focus group discussion and field obervation were used for data collection.

Results: Biogas technology adoption reduced the use of firewood, charcoal, dung cake, and kerosene consumption by $58 \%, 36 \%, 71 \%$, and $74 \%$, respectively. It also reduced the use of chemical fertilizer by $94 \%$ and the combined use of chemical fertilizer and manure by $91 \%$. Adoption turned the majority of households $(65.4 \%)$ to use combination of bio-slurry and chemical fertilizer. It helped the majority (89.95\%) of adopters to construct and connect toilets to biogas operational system. In doing so, adoption reduced defecation in the field and improved environmental sanitation and human health. It further enabled saving of about $38 \%$ of adopters' time, which otherwise would be expended for firewood and dung collection. It similarly enhanced adopters' income through decreasing expenses for chemical fertilizer, kerosene, and other fuel sources.

Conclusions: Biogas technology has huge potential of replacing traditional fuel sources for domestic consumption, and of reducing the consumption of kerosene and chemical fertilizers as well as of increasing income and decreasing time for biofuel collection.

\section{Background}

Biogas is combustible mixture of gas. It consists mainly of methane and carbon dioxide and is made from decomposition of organic compounds by anaerobic bacteria. It is a methane rich fuel gas produced by anaerobic digestion of organic materials with the help of methanogenic bacteria. Biogas technology offers a very attractive route to utilize certain categories of biomass for meeting partial energy needs (Molina et al., 2007). It provides an alternative energy source to the use of traditional fuel sources, which is dominantly used in most developing countries. Biogas technology serves two major purposes, biogas and bio-slurry. Biogas energy could replace the use of firewood, charcoal and kerosene for cooking, heating and lighting while bio-slurry could replace the use of chemical fertilizer for agricultural production (Sime et al., 2020).

Ethiopia is one of the developing countries that extremely relies on biomass for cooking and lighting (Lakew, 2010, Sime et al., 2020). The predominant cooking biomass energy source is firewood (77\%), followed by cow dung cake (13\%), crop residues (9\%), and charcoal (1\%). Kerosene (56\%) is the central energy source for lighting, followed by a rechargeable electric battery $(14 \%)$ in rural Ethiopia. Over $92 \%$ of the domestic energy demands are meeting from biomass-based fuels. Unsustainable cutting down of trees for firewood has directly caused significant deforestation, land degradation and soil erosion. The 
use of crop residues and dung cakes as substitute of firewood has further intensified problems related to land degradation and agricultural underproduction (Sime et al., 2020).

In the study area, scarcity of firewood has led to increased utilization of dung and agricultural residues for cooking, which otherwise would have been used to enhance forest cover, soil fertility and agricultural productivity. The undergoing biogas domestication activity in Ethiopia and the utilization of the potential of biogas technology has been low. The technical potential of biogas technology in replacing biomass resources for domestic energy utilization have not been studied. On the other hand, most of the previous studies conducted so far are associated with factors hindering or fostering the adoption of biogas technology (Shallo and Sime, 2019, Shallo et al., 2020, Abadi et al., 2017, Berhe et al., 2017, Kamp and Bermúdez Forn, 2016). Other studies include: prospects of domestic biogas technology (Desalegn, 2014), and contribution of biogas technology adoption to rural livelihood and environment health improvement (Mengistu et al., 2016 Amare, 2015). None of these studies have offered detailed attention to the evaluation of the technical potential of biogas technology in replacing firewood, charcoal, kerosene and chemical fertilizer. Thus, the objective of this study was to answer the technical potential of biogas technology in replacing firewood, charcoal, kerosene and chemical fertilizer in Southern Ethiopia.

\section{Materials And Methods}

\section{Description of the study area}

\section{Location}

Misrak and Mirab Estie Districts are located in South Gondar zone, Amhara Regional State, Northern Ethiopia (Fig. 1). Misrak Esite District is located at 7 $40^{\prime} \mathrm{N}$ latitude and $36^{\circ} 50^{\prime} \mathrm{E}$ longitude and at 96 kilometer from Bahir Dar, the capital city of Amhara Regional State and at 46 kilometer from Debre Tabor, the capital city of South Gondar zone. The District has 43 Kebele (5 urban and 38 rural villages), and is bordered by Abay River in the South, by Dera district in the West, by Farta in the North and by Simada in the East. Mirab Estie lies within $11^{0} 10^{\prime}$ to $11^{0} 30^{\prime}$ North latitude and $37^{0} 45^{\prime}$ to $38^{\circ}$ to $00^{\prime} E$ longitudes. It is located at 148 kilometers from Bahir Dar, the capital city of Amhara Regional State and at 91 kilometers from Debre Tabor, the capital city of South Gondar zone. This District has 24 Kebele (2 urban and 22 rural villages), and is bordered by Misrak Estie in Northeast and by Abay River in the South and by Dera in the West.

\section{The topography}

The topography of Misrak and Mirab Estie Districts comprises $41 \%$ plain, 47\% plateau and $12 \%$ deep gorge and other features according to District Agriculture Office. It has wide variation in altitude, ranging from less than 1500 to more than 2300 meter above sea level.

\section{Agro-climatic conditions}


The Districts have three agro-ecological zones. They include Dega with an altitude of more than 2300 meter above sea level, Woina-dega with an altitude of 1500-2300 meter above sea level and Kolla with an altitude of less than 1500 meters above sea levels. Dega, Woina-dega and Kolla cover about 3\%, 91\% and $6 \%$, respectively. The maximum and minimum annual temperature is $25^{\circ} \mathrm{C}$ and $8.3^{\circ} \mathrm{C}$, respectively.

\section{Demographic and socio-economic characteristics of the Districts}

The Central Statistical Agency (CSA) of Ethiopia indicated that Misrak Estie has an estimated total population of 403,956, of whom 199,325 are men and 204,631 are women. With an estimated area of $2,368.13 \mathrm{~m}^{2}$, the District has an estimated population density of 170.6 people per $\mathrm{m}^{2}$. Teff, maize, barley, potato, bean and wheat are the major crops grown. The main livestock type are cattle, sheep, goat, poultry, mule and donkey (CSA, 2015).

The total population size in Mirab Estie District is 137,767, out of which 70,077 are male and 67,690 are female. The District's total size of land area is 98,216 hectare with population density of 173.3 person per $\mathrm{m}^{2}$. The main crops grown are teff, maize, barley, potato and bean. Livestock rearing is part of mixed of livestock - crop production system as the basis of the main source of livelihood. The main livestock types are cattle, sheep, goat, poultry, mule and donkey (CSA, 2015).

Table 1

Size of livestock in study Districts

\begin{tabular}{|lll|}
\hline Livestock holding size & Misrak Estie District & Mirab Estie District \\
\hline Cattle & 78,964 & 89,608 \\
\hline Sheep & 58,529 & 125,241 \\
\hline Doat & 33,348 & 25,107 \\
\hline Mule & 8,111 & 8,835 \\
\hline Horse & 4,539 & 974 \\
\hline Poultry & 7,958 & 886 \\
\hline Total & 61,371 & 73,440 \\
\hline
\end{tabular}

\subsection{Approaches to data collection, sample size determination and sampling techniques}

A research design incorporating both qualitative and quantitative research approaches were employed for data collection. Qualitative approach was employed for gathering information through undertaking key informant interview, focus group discussion and field observation. The quantitative approach used household questionnaire survey for gathering quantitative data. 
All the 74 biogas user households and all the 16 biogas user Kebeles in both Districts were considered in this study (Table 2). Official list of the 16 biogas user Kebeles and the 74 user household heads was provided by the respective Biogas Coordinators of Misrak and Mirab Estie Districts.

Table 3

Study Districts and Kebeles, and their corresponding number of installed biogas plants

\begin{tabular}{|c|c|c|c|}
\hline Misrak Estie District & & & lirab Estie District \\
\hline Kebele Installed biogas plants & & \multicolumn{2}{|c|}{ Kebele Installed biogas plants } \\
\hline Agona Kositet & 4 & Deriba Betanisa & 5 \\
\hline Debir Zewana & 9 & Gishina & 4 \\
\hline Mekane Eyesus & 3 & Merji Tenikot & 4 \\
\hline Goshiberet & 4 & MesiBekilo Filega & 4 \\
\hline Licha Arida & 6 & Sheme Mosha & 5 \\
\hline Liwaye Ashama & 7 & Simet Sholaye & 3 \\
\hline Mikrie Kuskuam & 4 & Yedi Digmegn & 3 \\
\hline Jibasra Mariam & 5 & \multirow[t]{3}{*}{ Total size } & \multirow[t]{3}{*}{28} \\
\hline Ziguara & 4 & & \\
\hline Total size & 46 & & \\
\hline
\end{tabular}

Primary data were collected using questionnaires, semi-structure interview, focus group discussion and field observation. The 74 household heads were interviewed through administering questionnaire. In addition, a total of seven key informants (five biogas users and two-biogas coordinators) were purposefully selected. Then, the key informants were interviewed upon their consent using interview checklists. Key informants are individuals who are knowledgeable, open-minded, articulate, and cooperative for research interview purpose (Neergaard and Ulhøi, 2007). Focus group discussion was also held with group of biogas users belonging to different age and sex categories. Three focus group discussion per sample District were held. Each group has six members. The optimum size for a focus group discussion ranges from six to eight members (Bloor, 2001, Ritchie et al., 2013). Responses from both the interviews and discussion were recorded with a tape recorder. User voices were also recorded in videos upon their consent.

The field observations were conducted along with other data collection activities. Biogas plant feeding materials, major fuel sources, market value of household fuel at local market (charcoal, firewood, and kerosene and dung cake) and the use of chemical fertilizer and bio-slurry were observed.

\section{Data analysis}


All the data collected were entered into Microsoft Office and statistical analysis was done using SPSS-20 software. Descriptive statistics, chi-square, one sample t-test was used for analysis of data obtained from questionnaire at $95 \%$ confidence interval and $p$-value $<0.05$.

\section{Results And Discussion}

\section{Socio- economic characteristics of user households Cattle holding size}

About $55.4 \%, 32 \%, 5.4 \%$, and $6.8 \%$ of the households had cattle holding size ranging from $1-3,4-5,6-7$ and $>7$, respectively. The average cattle holding size was three cattle per household, which is less than the minimum standard set by the National Biogas Program of 4 cows for installing biogas plants (Table 3). One sample T- test result showed that livestock size has a significant $(p<0.05)$ positive association with the adoption of biogas technology. Field observations of biogas plants also showed that the availability of sufficient cattle dung, which is the primary feedstock for biogas plants, is the most important factor in daily biogas operation. Thus, the quantity of dung available per day is critical in realizing the benefit and viability of biogas technology. Eshete et al. (2006) indicated that rural households in Ethiopia would need at least four cattle stabled during the night to get a minimum of $20 \mathrm{~kg}$ of fresh animal dung per plant per day, which is the size required to produce enough biogas energy for cooking or lighting (EREDPC and SNV, 2008). Other findings from previous studies indicated that cattle size has a significant positive association with adoption of biogas technology (Walekhwa et al., 2009, Kabir et al., 2013, Shallo and Sime, 2019).

Table 3

Cattle holding size of biogas user households

\begin{tabular}{|c|c|c|c|}
\hline Number of cattle & Frequency & Percent & One sample T-test result \\
\hline $1-3$ & 41 & 55.4 & \multirow[t]{5}{*}{$p$-value $=0.00$} \\
\hline $4-5$ & 24 & 32.4 & \\
\hline $6-7$ & 4 & 5.4 & \\
\hline 7 & 5 & 6.8 & \\
\hline Total & 74 & 100.0 & \\
\hline
\end{tabular}

In terms of cattle grazing systems, about $31.1 \%$ of the households used free grazing on open field, $40.5 \%$ controlled grazing (zero grazing practice) and the remaining $28.4 \%$ used combined together free grazing on open field and controlled grazing. On the other hand, about $59.5 \%$ of the households got sufficient cattle dung while $40.5 \%$ lacked sufficient cattle dung for feeding biogas plants. The latter households had their cattle grazing freely moving on open fields. Furthermore, $40.5 \%$ of the households collected dung 
from various sources while the remaining 59.5\% did not. Among those households collecting cow dung, $26.6 \%$ collected dung from field, $43.3 \%$ from stall (locally called Beret) and the remaining $30 \%$ from stall and field (Table 4). Field observation also showed that households practicing controlled grazing method have better potential of adopting biogas technology than those practicing other methods of grazing types. Controlled grazing was observed to ease dung collection, lessening labor and time. Mwirigi et al. (2009) reported a significant positive relationship between grazing system and adoption of biogas technology in Kenya.

Table 4

Grazing types and dung collection

\begin{tabular}{|llll|}
\hline Variable & Type of grazing & Frequency & Percent \\
\cline { 2 - 4 } $\begin{array}{l}\text { What grazing type do you use for feeding your } \\
\text { cattle? }\end{array}$ & $\begin{array}{l}\text { Free grazing on open } \\
\text { field }\end{array}$ & 23 & 31.1 \\
& Controlled grazing & 30 & 40.5 \\
& $\begin{array}{l}\text { Free grazing on open } \\
\text { field }\end{array}$ & 21 & 28.4 \\
& and controlled grazing & 74 & 100.0 \\
& Total & & \\
\hline $\begin{array}{l}\text { Do you have sufficient cattle dung for biogas } \\
\text { plants? }\end{array}$ & Yes & 44 & 59.5 \\
& No & 30 & 40.5 \\
\hline Do you collect cattle dung from various sources? & Total & 74 & 100.0 \\
& No & 30 & 40.5 \\
& Total & 44 & 59.5 \\
\hline If Yes, from where do you collect cow dung? & Field & 74 & 100.0 \\
& Stall (Beret) & 8 & 26.6 \\
& Both field and stall & 9 & 43.3 \\
\hline
\end{tabular}

\section{Traditional biomass energy use pattern}

The energy use pattern showed that an extensive number of households use firewood (41.9\%), followed by dung cake (29.7\%), charcoal (17.6\%) and kerosene (10.8\%) before biogas technology adoption (Fig. 2). Firewood becomes an indispensable source of fuel for cooking, followed by charcoal. This shows that traditional biomass are major sources of domestic energy (89.2\%) in the study areas. About $95 \%$ of the Ethiopian population relies on traditional biomass fuels for cooking (Sanbata et al., 2014). Gwavuya et al. 
(2012) reported that firewood holds the greatest share of energy sources for cooking in rural Ethiopia. Besides, kerosene was mainly used for lighting. Kerosene is the major energy source for lighting in rural areas in Ethiopia (Sime et al., 2020).

\section{Quantity of firewood consumption}

About $70.3 \%$ of households consumed $3-5$ bundles of firewood, $23 \%$ consumed $6-7$ bundles of firewood and $6.8 \%$ consumed $8-9$ bundles of firewood per month. This is, on average, equivalent to the consumption of 4.8 bundles of firewood per household per month or 57.6 bundles of firewood per year before adoption. After adoption, $81.1 \%$ of the households used $1-2$ bundles of firewood, $10.8 \%$ used 3-4 bundles of firewood and $8.1 \%$ used 5-6 bundles of firewood per household per month, with an average consumption of 2.0 bundles of firewood per household per month. This is a reduction of more than $50 \%$ of the bundles of firewood used per household per month or is a reduction of 33.6 bundles of firewood per year. Thus, biogas technology adoption enabled the saving of 33.6 bundles of firewood annually. This is equivalent to saving 3010.56 ETB annually at a local price rate of 89.6 ETB per bundle of firewood (Table 5). Amare (2015) reported that biogas technology adoption enabled a reduction of $70.47 \%$ of firewood per household per year. This is a reduction in annual firewood consumption, approximately of 79 bundles of firewood per household per year. In turn, this is equivalent saving 3833.22 ETB annually at local rate of 48.40 ETB per $32 \mathrm{~kg}$ per bundle. A reduction of $45 \%$ in firewood consumption was also reported because of partial replacement of traditional fuels with biogas energy (Abadi et al., 2017). Similarly, other previous studies also showed that biogas users tend to consume less firewood than nonusers do (Christiaensen and Heltberg, 2014). 
Table 5

Number of bundles of firewood consumption per household per month before and after adoption of biogas technology

\begin{tabular}{|c|c|c|c|c|c|}
\hline \multirow[b]{2}{*}{ Number of bundle } & \multicolumn{2}{|c|}{ Before adoption } & \multicolumn{3}{|c|}{ After adoption } \\
\hline & Frequency & Percent & $\begin{array}{l}\text { Number of } \\
\text { bundle }\end{array}$ & Frequency & Percent \\
\hline $3-5$ & 52 & 70.3 & $1-2$ & 60 & 81.1 \\
\hline $6-7$ & 17 & 23.0 & $3-4$ & 8 & 10.8 \\
\hline $8-9$ & 5 & 6.8 & $5-6$ & 6 & 8.1 \\
\hline Total & 74 & 100.0 & Total & 74 & 100.0 \\
\hline Average $=4.8$ & & & Average $=2$ & & \\
\hline \multirow{6}{*}{\multicolumn{3}{|c|}{$\begin{array}{l}\text { How much is the price of one bundle in your local market } \\
\text { (ETB)Amare (2015)? }\end{array}$}} & Price & Frequency & Percent \\
\hline & & & $80-90$ & 42 & 56.8 \\
\hline & & & $91-100$ & 31 & 41.9 \\
\hline & & & $101-110$ & 1 & 1.4 \\
\hline & & & Total & 74 & 100.0 \\
\hline & & & $\begin{array}{l}\text { Average }= \\
89.6\end{array}$ & & \\
\hline
\end{tabular}

\section{Quantity of dung cake consumption}

Dung cake is regularly used as traditional fuel in traditional stoves in most parts of Ethiopia. Before adoption, about $56.8 \%$ of the households consumed 6,065 dung cakes, $32.4 \%$ consumed $66-70$ dung cakes and the rest $10.8 \%$ consumed $71-75$ dung cakes per month, with an average consumption of 65.4 dung cakes per household per month. However, after adoption, $82.8 \%$ of the households used $15-20$ dung cakes, $13.5 \%$ used $21-25$ dung cakes and $4.1 \%$ used $26-30$ dung cakes per household per month, with an average consumption of 18.6 dung cakes per household per month. This is a reduction of 46.8 dung cakes per household per month. Thus, the adoption of biogas technology enabled the saving of 561.6 dung cakes per household per year. This is in turn equivalent to saving 1684.8 ETB per year at a local price rate of three ETB per dung cake (Table 6). Amare (2015) reported that adoption of biogas technology enabled a saving of $600 \mathrm{~kg}$ of dung cakes per year, which is equivalent to saving 1,662 ETB per year in Amhara Region in Norther Ethiopia. 
Table 6

Number of dung cake consumption of household per month before and after adoption of biogas technology

\begin{tabular}{|c|c|c|c|c|c|}
\hline \multirow[t]{2}{*}{ Number of dung cake } & \multicolumn{2}{|c|}{ Before plant installation } & \multirow[t]{2}{*}{$\begin{array}{l}\text { Number of dung } \\
\text { cake }\end{array}$} & \multicolumn{2}{|c|}{ After plant installation } \\
\hline & Frequency & Percent & & Frequency & Percent \\
\hline $60-65$ & 42 & 56.8 & $15-20$ & 61 & 82.4 \\
\hline $66-70$ & 24 & 32.4 & $21-25$ & 10 & 13.5 \\
\hline $71-75$ & 8 & 10.8 & $36-30$ & 3 & 4.1 \\
\hline Total & 74 & 100.0 & Total & 74 & 100.0 \\
\hline Average $=65.4$ & & & $\begin{array}{l}\text { Average }= \\
18.6\end{array}$ & & \\
\hline \multirow{2}{*}{\multicolumn{3}{|c|}{$\begin{array}{l}\text { How much is the price of one dung cake in your } \\
\text { local market? }\end{array}$}} & Price (ETB) & Frequency & Percent \\
\hline & & & $1-2$ & 17 & 23.0 \\
\hline & y cane to tito & & $3-4$ & 55 & 74.3 \\
\hline & & & $5-6$ & 2 & 2.7 \\
\hline & & & Total & 74 & 100.0 \\
\hline
\end{tabular}

\section{Quantity of charcoal consumption}

Table 8 presents consumption of charcoal (in sacks) before and after adoption of biogas technology. Accordingly, $59.4 \%$ of the households consumed 1 sack of charcoal, $33.7 \%$ consumed $1.5-2$ sacks of charcoal and $6.7 \%$ consumed 2.25-2.5 sacks of charcoal per month, with an average consumption of 1.4 sacks of charcoal per household per month or 16.8 sacks of charcoal per year before adoption. After adoption, $70.3 \%$ (majority of biogas users) of households consumed 0.25 sacks of charcoal, $28.4 \%$ consumed 0.5 sacks of charcoal and $1.4 \%$ consumed 1 sacks of charcoal per month, with an average consumption of 0.5 sacks of charcoal per household per month. This is a reduction of 0.9 sacks of charcoal per households per month or 10.8 sacks of charcoal per year (Table 7). In monetary terms, this is equivalent to saving 2872.8 ETB annually at local rate of 266 ETB per sack of charcoal. Amare (2015) reported that adoption of biogas technology enabled households replacing 12 sacks of charcoal per household per year, which is equivalent to saving 1,243.20 ETB per household per year at the local rate of 103.60 ETB. 
Table 7

Quantity of charcoal consumption (in sacks) per household per month before and after biogas plant installation

\begin{tabular}{|c|c|c|c|c|c|}
\hline \multicolumn{4}{|c|}{ Before adoption } & \multicolumn{2}{|c|}{ After adoption } \\
\hline No. of sack & Frequency & Percent & No. of sack & Frequency & Percent \\
\hline 1 & 44 & 59.4 & 0.25 & 52 & 70.3 \\
\hline $1.5-2$ & 25 & 33.7 & 0.5 & 21 & 28.4 \\
\hline $2.25-2.5$ & 5 & 6.7 & 1 & 1 & 1.4 \\
\hline Total & 74 & & Total & 74 & 100.0 \\
\hline Average $=1$ & & & $\begin{array}{l}\text { Average }= \\
0.5\end{array}$ & & \\
\hline \multirow{5}{*}{\multicolumn{3}{|c|}{$\begin{array}{l}\text { How much is the price of one sack of charcoal in your } \\
\text { local market? }\end{array}$}} & $250-260$ & 17 & 23 \\
\hline & & & $261-270$ & 34 & 45.9 \\
\hline & & & $271-280$ & 23 & 31.1 \\
\hline & & & Total & 74 & 100.0 \\
\hline & & & $\begin{array}{l}\text { Average }= \\
266\end{array}$ & & \\
\hline
\end{tabular}

\section{Analysis and estimation of time requirement for traditional fuel collection}

To collect firewood and cattle dung, about $58.1 \%$ of households took $8-9 \mathrm{~h}, 23.0 \%$ took $10-11 \mathrm{~h}$ and the remaining $18.9 \%$ took $12-13 \mathrm{~h}$ per household per week before adoption of the biogas technology. This is on average equivalent to $12 \mathrm{~h}$ per household per week, $48 \mathrm{~h}$ per household per month or $576 \mathrm{~h}$ per year. After adoption, about $64.9 \%$ of user households took $3-4 \mathrm{~h}, 18.9 \%$ took $5-6 \mathrm{~h}$ and the remaining $16.2 \%$ took 12-13 h to collect firewood and cow dung per household per week (Table 8 ). This is, on average, equivalent to $4.5 \mathrm{~h}$ per household per week, $18 \mathrm{~h}$ per household per month or $216 \mathrm{~h}$ per year. Thus, biogas technology adoption enabled biogas user to save an average time of $7.5 \mathrm{~h}$ per household per week, $30 \mathrm{~h}$ per month or $360 \mathrm{~h}$ per year, which is about $38 \%$. Among household members, primarily women and girls are the ones who collect firewood from various sources and engage in cooking activities. Thus, adoption of biogas technology predominantly enables women and girls save time to be spent for firewood collection and cooking. The saved time enhanced women's socioeconomic engagements: petty trading, executing agricultural activities and undertaking other social obligations. Adoption also increased the number girls attending schools. The time saved following biogas technology adoption is utilized for schooling or other productive purposes (Sime, 2020). The use of biogas narrowed the gap in educational status between males and females (Arthur et al., 2011, Sime, 2020). The reduced workload from women and children in association with firewood or cow dung collection and the availability of clean household energy lead to social and economic development (Garfí et al., 2012). Domestic biogas energy reduces the 
workload of women by reducing the need to collect firewood, tend fires and clean soot from cooking utensils (Eshete et al., 2006, Gwavuya et al., 2012, Amare, 2015).

Table 8

Time requirement before and after adoption of biogas technology

\begin{tabular}{|c|c|c|c|}
\hline \multirow{5}{*}{$\begin{array}{l}\text { Time requirement } \\
\text { How long does it take you to collect firewood and cattle dung } \\
\text { before biogas plant installation? Hour per week } \\
\text { Average time = } 12 \text { hours/week }\end{array}$} & $\begin{array}{l}\text { Hour } \\
\text { per } \\
\text { week }\end{array}$ & Frequency & Percent \\
\hline & $8-9$ & 43 & 58.1 \\
\hline & $10-11$ & 17 & 23.0 \\
\hline & $12-13$ & 14 & 18.9 \\
\hline & Total & 74 & 100.0 \\
\hline \multirow{2}{*}{$\begin{array}{l}\text { How long does it take you to collect firewood and cattle dung } \\
\text { after biogas plant installation? Hour per week }\end{array}$} & $3-4$ & 48 & 64.9 \\
\hline & $5-6$ & 14 & 18.9 \\
\hline \multirow{2}{*}{ Average time $=4.5$ hours $/$ week } & $7-8$ & 12 & 16.2 \\
\hline & Total & 74 & 100 \\
\hline
\end{tabular}

\section{Quantity of kerosene consumption}

With regard to kerosene consumption, about $43.9 \%$ (the majority) of households consumed 1-2 liter of kerosene, $45.5 \%$ consumed $3-4$ liters and only $10.5 \%$ consumed greater than 4 liter of kerosene per month, with an average consumption of 2.7 liter of kerosene per household per month or 32.4 liter of kerosene per year before adoption. However, after adoption, $51.5 \%$ of the households consumed $0.25-0.5$ liter of kerosene, with an average consumption of 0.7 liter of kerosene per household per month (Table 9). This is a reduction of 2 liter kerosene per household per month or 24 liter kerosene per year. This shows that biogas adoption enabled saving of 24 liter of kerosene annually. This is equivalent to saving 456 ETB annually at a local rate of 19 ETB per liter of kerosene. Simur Asres (2012) estimated the daily consumption of kerosene of 0.13 liter per day per household, which is equivalent to saving 47.43 liter of kerosene per household per year and saving 617 ETB based on local price of 13 ETB per liter in Amhara Region in Northern Ethiopia. 
Table 9

Consumption of kerosene per household per month before and after adoption of biogas technology

\section{Question}

Do you purchase kerosene?

\begin{tabular}{lll|} 
Variable & Frequency & Percent \\
\hline Yes & 66 & 89.2 \\
\hline No & 8 & 10.8 \\
\hline Total & 74 & 100.0
\end{tabular}

If yes, at what price do you buy one liter of kerosene?

Average price was 19 ETB per liter

\begin{tabular}{lll}
\hline $16-18$ & 26 & 39.4 \\
\hline $19-21$ & 33 & 50.0 \\
\hline $22-23$ & 7 & 10.6 \\
\hline Total & 66 & 100.0 \\
\hline
\end{tabular}

Before adoption

After adoption

$\begin{array}{llllll}\text { Liter } & \text { Frequency } & \text { Percent } & \text { Liter } & \text { Frequency } & \text { Percent } \\ 1-2 & 29 & 43.9 & 0.25-0.5 & 34 & 51.5 \\ 3-4 & 30 & 45.5 & 0.75-1.0 & 18 & 28.3 \\ >4 & 7 & 10.5 & 1.5-1.75 & 14 & 21.2 \\ \text { Total } & 66 & 100.0 & \text { Total } & 66 & 100.0 \\ \text { Average }=2.7 & & & \text { Average }= \\ & & & 0.7\end{array}$

\section{Quantity of chemical fertilizer consumption}

There are two kinds of chemical fertilizers that are widely used in Ethiopia. They are DAP and urea, the former is phosphorus fertilizer while the later one is nitrogen fertilizer. Before adoption, about $41.9 \%$ of the households used chemical fertilizer only while $47.3 \%$ of them used both chemical fertilizer and manure. The rest of the households used compost, manure or their combination. However, after adoption, $50 \%$ of the households used chemical fertilizer and bio-slurry, $35.1 \%$ used bio-slurry and compost and the remaining used chemical fertilizer only, manure and compost and chemical fertilizer and manure (Table 10). The use of chemical fertilizer was reduced from $41.9-2.7 \%$, which is equivalent to $94 \%$ reduction. Similarly, the combined use of chemical fertilizer and manure was reduced from 47.3 to $4.1 \%$, which is again equivalent to $91 \%$ reduction. Furthermore, field observations showed that the use of bioslurry has increased following adoption. The majority of adopter households, which is about $65.4 \%$, also used combination of bio-slurry and chemical fertilizer together. Debebe and Itana (2016) reported that $15.4 \%$ biogas adopter households used chemical fertilizer only, $11.5 \%$ used cow dung, compost and chemical fertilizer, while the remaining $7.7 \%$ used bio-slurry, compost and chemical fertilizer. 
Table 10

Fertilizer use pattern before and after adoption of biogas technology

\begin{tabular}{|c|c|c|c|}
\hline Question & Fertilizer type & Frequency & Percent \\
\hline \multirow{6}{*}{$\begin{array}{l}\text { What type of fertilizer do you } \\
\text { use before biogas adoption? }\end{array}$} & Chemical fertilizer only & 31 & 41.9 \\
\hline & Compost & 5 & 6.8 \\
\hline & Manure & 2 & 2.7 \\
\hline & $\begin{array}{l}\text { Chemical fertilizer and } \\
\text { manure }\end{array}$ & 35 & 47.3 \\
\hline & $\begin{array}{l}\text { Chemical fertilizer and } \\
\text { compost }\end{array}$ & 1 & 1.4 \\
\hline & Total & 74 & 100.0 \\
\hline \multirow{7}{*}{$\begin{array}{l}\text { What type of fertilizer do you use after biogas } \\
\text { adoption? }\end{array}$} & Fertilizer type & Frequency & Percent \\
\hline & Chemical fertilizer only & 2 & 2.7 \\
\hline & Bio-slurry and compost & 26 & 35.1 \\
\hline & Manure and compost & 6 & 8.1 \\
\hline & $\begin{array}{l}\text { Chemical fertilizer and } \\
\text { manure }\end{array}$ & 3 & 4.1 \\
\hline & $\begin{array}{l}\text { Chemical fertilizer and } \\
\text { bio-slurry }\end{array}$ & 37 & 50.0 \\
\hline & Total & 74 & 100.0 \\
\hline
\end{tabular}

Likewise, about $62.2 \%$ of households, which is the majority, used 4 sacks of DAP and 1 sack of urea, $37.8 \%$ used 5 sacks of DAP and 2 sacks of urea per hectare per year, with an average consumption of 4.5 sacks of DAP and 1.5 sacks of urea before adoption (1 sack weighs $50 \mathrm{~kg}$ ). Whereas, after adoption, about $45.9 \%$ of the households used 1 sack of DAP and 0.25 sack of urea. About $54.1 \%$, which is the majority, used 2 sacks of DAP and 0.5 sack of urea per hectare per year, with an average consumption of 1.5 sacks of DAP and 0.37 sack of urea per household per hectare per year (Table 11). This is a reduction of 3 sacks of DAP and 1 sack of urea per household per hectare per year. Thus, adoption enabled the saving of 3 sacks of DAP and 1 sack of urea per hectare per year. In terms of monetary returns, this is equivalent to saving of 2265.00 ETB from DAP and 695.00 ETB from urea purchase annually per hectare at local rate ( 1 sack or $50 \mathrm{~kg}$ DAP $=755 \mathrm{ETB}, 1$ sack per $50 \mathrm{~kg}$ urea $=695 \mathrm{ETB}$, at the time of data collection). Thus, the adoption has remarkably reduced the quantity of chemical fertilizer consumption. Debebe and Itana (2016) stated that chemical fertilizer is very expensive as compared to bio-slurry, $80.8 \%$ of the bio-slurry users saved 1000-2000 ETB per year and 19.2\% saved 2000-3000 ETB per year. Similarly, Amare (2015) reported that the use of biogas offered an annual saving of 717.65 ETB and Claudia and Addis (2011) of 682 ETB from replacing inorganic chemical fertilizer with chemical fertilizer. 
The difference in the amount of money saved might infer to soil fertility, type of crop grown, and tradition of using chemical fertilizer and bio-slurry.

\section{Table 41}

Amount of chemical fertilizer used before and after biogas technology adoption

\begin{tabular}{|c|c|c|c|}
\hline \multirow{4}{*}{$\begin{array}{l}\text { Question } \\
\text { How many sacks of chemical fertilizer do use } \\
\text { before biogas technology } \\
\text { adoption per hectare per season? Average = } 4.5 \text { sack } \\
\text { DAP and } 1.5 \text { sack urea }\end{array}$} & \multirow{2}{*}{$\begin{array}{l}\text { Amount and } \\
\text { type of } \\
\text { fertilizer } \\
4 \text { sack DAP } \\
\text { and } 1 \text { sack } \\
\text { urea }\end{array}$} & Frequency & Percent \\
\hline & & 46 & 62.2 \\
\hline & $\begin{array}{l}5 \text { sack DAP } \\
\text { and } 2 \text { sack } \\
\text { urea }\end{array}$ & 28 & 37.8 \\
\hline & Total & 74 & 100.0 \\
\hline \multirow{2}{*}{$\begin{array}{l}\text { How many sacks of chemical fertilizer do } \\
\text { use after biogas technology } \\
\text { adoption per hectare per season? }\end{array}$} & & & \\
\hline & 1 sack DAP & 34 & 45.9 \\
\hline \multirow[t]{3}{*}{ Average $=1.5$ sack DAP and 0.37 sack urea } & urea & & \\
\hline & $\begin{array}{l}2 \text { sack DAP } \\
\text { and } 0.5 \text { sack } \\
\text { urea }\end{array}$ & 40 & 54.1 \\
\hline & Total & 74 & 100.0 \\
\hline $\begin{array}{l}\text { How much is the price of one sack }(50 \mathrm{~kg}) \text { chemical } \\
\text { fertilizer in your local market? }\end{array}$ & Price & Frequency & Percent \\
\hline \multirow[t]{3}{*}{ Average $=755$ ETB DAP and 695 ETB urea } & $\begin{array}{l}750 \text { ETB DAP } \\
\text { and } 690 \text { ETB } \\
\text { urea }\end{array}$ & 51 & 68.9 \\
\hline & $\begin{array}{l}760 \text { ETB DAP } \\
\text { and } 700 \text { ETB } \\
\text { urea }\end{array}$ & 23 & 31.1 \\
\hline & Total & 74 & 100.0 \\
\hline
\end{tabular}

\section{Access to water sources}

Though about $29.7 \%$ of the households had access to water sources around their home, the majority of the households, which is about $70.3 \%$, lacked access to such water sources. The water resource was mostly reached within 50 minutes of walking distance from their residence. Consequently, the majority of the households, which is $62.5 \%$, use water from rivers and $16.7 \%$ from water tap, and $12.5 \%$ from rain water harvesting (Table 12). According to the standard set in the National Biogas Program document, for daily feeding of biogas plants, the source of water should be reached within walking distance of 20 minutes to 30 minutes away from home in Ethiopia (Eshete et al., 2006, EREDPC and SNV, 2008). Distant 
water source had negative influence on the functionality of biogas plants (Shallo and Sime, 2019). Tucho et al. (2016) also reported that meeting biogas plant's water requirement remained a great challenge when distant water sources are considered. Since water is a basic substrate for biogas production, access to water sources is instrumental for the sustainable adoption of biogas technology. Thus, limited water availability is a basic constraint for biogas operation in some African countries (Parawira, 2009, Wawa, 2012, Surendra et al., 2014).

Table 12

Accessibility and type of sources of water

\begin{tabular}{|llll|}
\hline Accessibility & Source of water & Frequency & Percent \\
\hline Do you get water at your home/residence? or & & 22 & 29.7 \\
\hline away from residence area? & & 52 & 70.3 \\
\hline \multirow{2}{*}{$\begin{array}{l}\text { If you do not get water in the nearest, } \\
\text { from where do you fetch? }\end{array}$} & Total & 74 & 100.0 \\
\cline { 2 - 4 } & River & 30 & 62.5 \\
\cline { 2 - 4 } & Water well & 4 & 8.3 \\
\cline { 2 - 4 } & Water tap & 8 & 16.7 \\
\cline { 2 - 4 } & Rainwater & 6 & 12.5 \\
\cline { 2 - 4 } & Total & 48 & 100.0 \\
\hline
\end{tabular}

\section{Connection of toilet to biogas plants}

All biogas user households had toilets. About $89.2 \%$ of them connected their toilets to the biogas system while $10.8 \%$ of them lacked such a connection. Before adoption, the trend of using toilet were poor (39.2\%), very poor (41.9\%), good (10.8\%) and very good (8.1\%). Nevertheless, after adoption, the trend was soundly changed where about $40.5 \%$ were good, $36.5 \%$ were very good, $14.9 \%$ were poor and $8.1 \%$ were very poor (Table 13). Biogas technology adoption helped the majority of biogas users to construct toilets and reduce defecation in the field, with massive potential of improving environmental sanitation and human health. 
Table 5

Trend of using toilets and connection of toilets with biogas system

\begin{tabular}{|lllll|}
\hline Trend of using toilet & \multicolumn{2}{c|}{ Before adoption } & \multicolumn{2}{l|}{ After adoption } \\
\cline { 2 - 5 } & Frequency & Percent & Frequency & Percent \\
\hline Good & 8 & 10.8 & 30 & 40.5 \\
\hline Very good & 6 & 8.1 & 27 & 36.5 \\
\hline Poor & 29 & 39.2 & 11 & 14.9 \\
\hline Very poor & 31 & 41.9 & 6 & 8.1 \\
\hline Total & 74 & 100.0 & 74 & 100.0 \\
\hline Is your toilet connected & & Variable & Frequency & Percent \\
\cline { 3 - 5 } to biogas operational & & Yes & 66 & 89.2 \\
\cline { 3 - 5 } system? & & No & 8 & 10.8 \\
\cline { 3 - 5 } & & Total & 74 & 100.0 \\
\hline
\end{tabular}

Biogas technology improves health of rural households by providing a cleaner cooking fuel and a waste handling solution, thus, avoiding health problems (Amigun et al., 2012; Sime 2020). Cooking with clean and odorless flame of biogas enabled reduction of in-door pollution caused from the smell of kerosene or smoke of firewood burning (Bajgain and Shakya, 2005).

\section{Conclusion And Recommendation}

This study evaluated the technical potential of biogas technology to replace traditional fuel, kerosene and bio-slurry in northern Ethiopia. Biogas technology adoption soundly reduced households' firewood, charcoal, dung cake and kerosene consumption by $58 \%, 36 \%, 71 \%$, and $74 \%$, respectively. It similarly reduced the use of chemical fertilizer and combination of chemical fertilizer and manure by $94 \%$, and $91 \%$, respectively. The technology also enhanced adopters' annual income. Besides increasing the trend of constructing toilets, it reduced defecation in the field that massively improved environmental sanitation and human health. In conclusion, biogas technology offers a massive potential of reducing the consumption of firewood, charcoal, dung cake and kerosene, with huge implication for forest resource management and improvement of agricultural productivity, and human and environmental health. Future research need to focus on rectifying other challenges influencing the realization of the technical potential of biogas technology dissemination in Ethiopia.

\section{Declarations}

\section{Authors' contributions}


Both authors designed the research and conducted primary data collection and analysis for the studies. In addition, both authors edited and approved the final manuscript.

\section{Funding}

This study received funding support from Hawassa University, Ethiopia.

\section{Availability of data and materials}

Not applicable.

\section{Ethics approval and consent to participate}

Not applicable.

\section{Consent for publication}

Not applicable.

\section{Competing interests}

The authors declare that they have no competing interests.

\section{Acknowledgments}

The Graduate School of Hawassa University, Ethiopia, funded this research. We are grateful to the key informants, focus group discussants, energy experts and farmers for their unreserved assistance during the data collection. They provided useful insights to the researchers. The different district offices are also thanked for their generous hospitality and support.

\section{References}

1. ABADI N, TECHANE GEBREHIWOT,K, A. \& NEREA H (2017) Links between biogas technology adoption and health status of households in rural Tigray, Northern Ethiopia. Energy Policy 101:284292

2. AMARE ZY (2015) The benefits of the use of biogas energy in rural areas in Ethiopia: A case study from the Amhara National Regional State, Fogera District. African Journal of Environmental Science Technology 9:332-345

3. AMIGUN B, ABOYADE PARAWIRA,WMUSANGO,J, A. \& BADMOS A (2012) Anaerobic biogas generation for rural area energy provision in Africa. In: KUMAR, S. (ed.) Biogas. InTech

4. ARROYAVE-GARCIA JL, BERRUN-CASTANON J, FARIAS DIOSDADO,JM, GARCIA L, GARZA-ONDARZA AJ, GONZALEZ-GUERRA J, MAYORAL-RODRIGUEZ S, I. M., MORALES-PEREGRINA, J. J. \& PADILLACORTEZ, A (2002) Method and apparatus for recovering energy from wastes by combustion in industrial furnaces. Google Patents 
5. ARTHUR R, BAIDOO MF, ANTWI E (2011) Biogas as a potential renewable energy source: A Ghanaian case study. Renewable Energy 36:1510-1516

6. BAJGAIN S, SHAKYA IS (2005) A successful model of public private partnership for rural household energy supply. Kigali, Rwanda: SNV

7. BERHE TG, TESFAHUNEY, R. G., DESTA, G. A. \& MEKONNEN LS (2017) Biogas Plant Distribution for Rural Household Sustainable Energy Supply in Africa. Energy Policy Research 4:10-20

8. BLOOR M (2001) Focus groups in social research, Sage

9. CHRISTIAENSEN L, HELTBERG R (2014) Greening China's rural energy: new insights on the potential of smallholder biogas. Environ Dev Econ 19:8-29

10. CLAUDIA B, ADDIS Y (2011) Survey of biogas plants in four regional states of Ethiopia. SNVEthiopia, Addis Ababa, Ethiopia

11. CSA (2015) Report on area and production of crop and utilization of Ethiopia. Central Statistics Agency (CSA), Addis Ababa, Ethiopia

12. DEBEBE Y, ITANA F (2016) Comparative study on the effect of applying biogas slurry and inorganic fertilizer on soil properties, growth, and yield of white cabbage (Brassica oleracea var. capitata $f$. alba). Journal of Biology Agriculture Healthcare 6:19-26

13. DESALEGN Z (2014) Studies on Prospects and Challenges of Uptake of Domestic Bio-gas Technology (The case of SNNPR, ETHIOPIA). St. Mary's University

14. EREDPC \& SNV (2008) Ethiopian Rural Energy Development and Promotion Center (EREDPC) and Netherlands Development Organization (SNV). National Biogas Pro-gramme Ethiopia: Programme Implementation Document. EREDPC and SNV, Addis Ababa

15. ESHETE G, SONDER K, HEEGDE F (2006) Report on the feasibility study of a national programme for domestic biogas in Ethiopia. SNV Netherlands Development Organization, Addis Ababa

16. GARFÍ M, FERRER-MARTí L, VELO E, FERRER I (2012) Evaluating benefits of low-cost household digesters for rural Andean communities. Renew Sustain Energy Rev 16:575-581

17. GWAVUYA S, BARFUSS ABELE,S, ZELLER I, M. \& MÜLLER J (2012) Household energy economics in rural Ethiopia: A cost-benefit analysis of biogas energy. Renewable Energy 48:202-209

18. KABIR H, YEGBEMEY, R. N. \& BAUER S (2013) Factors determinant of biogas adoption in Bangladesh. Renew Sustain Energy Rev 28:881-889

19. KAMP LM, BERMÚDEZ FORN E (2016) Ethiopiaロs emerging domestic biogas sector: Current status, bottlenecks and drivers. Renew Sustain Energy Rev 60:475-488

20. LAKEW H (2010) Ethiopian energy sector review for up to 2008. Forum for Environment, Addis Ababa, pp 79-104

21. MENGISTU MG, SIMANE B, ESHETE G, WORKNEH TS (2016) Factors affecting households' decisions in biogas technology adoption, the case of Ofla and Mecha Districts, northern Ethiopia. Renewable Energy 93:215-227 
22. MOLINA F, RUIZ-FILIPPI G, GARCÍA C, ROCA E, LEMA, J. J. W. S. \& TECHNOLOGY 2007. Winery effluent treatment at an anaerobic hybrid USBF pilot plant under normal and abnormal operation. 56, $25-31$

23. MWIRIGI JW, MAKENZI PM, OCHOLA WO (2009) Socio-economic constraints to adoption and sustainability of biogas technology by farmers in Nakuru Districts, Kenya. Energy Sustain Dev 13:106-115

24. NEERGAARD H, ULHøI JP (2007) Handbook of qualitative research methods in entrepreneurship, Edward Elgar Publishing

25. PARAWIRA W (2009) Biogas technology in sub-Saharan Africa: status, prospects and constraints. Reviews in Environmental Science Bio/Technology 8:187-200

26. RITCHIE J, LEWIS, J., NICHOLLS, C. M. \& ORMSTON R (2013) Qualitative research practice: A guide for social science students and researchers, sage

27. SANBATA H, ASFAW, A. \& KUMIE A (2014) Indoor air pollution in slum neighbourhoods of Addis Ababa, Ethiopia. Atmos Environ 89:230-234

28. SHALLO L, AYELE M, SIME G (2020) Determinants of biogas technology adoption in southern Ethiopia. Energy Sustainability Society 10:1-13

29. SHALLO L, SIME G, J. I. J. OSE (2019) Determinants of functional status of family size bio-digesters: empirical evidence from southern Ethiopia. 38, 493-510

30. SIME G (2020) Technical and socioeconomic constraints to the domestication and functionality of biogas technology in rural areas of southern Ethiopia. Cogent Engineering 7:1765686

31. SIME G, TILAHUN G, KEBEDE M (2020) Assessment of biomass energy use pattern and biogas technology domestication programme in Ethiopia. African Journal of Science, Technology, Innovation and Development, 1-11

32. SIMUR ASRES T (2012) The Current Status of Traditional Biomas Enegry Utilization and Its Alternative Renewable Enegry Technology in Amhara

33. SURENDRA K, TAKARA D, HASHIMOTO, A. G. \& KHANAL SK (2014) Biogas as a sustainable energy source for developing countries: Opportunities and challenges. Renew Sustain Energy Rev 31:846859

34. TUCHO GT, MOLL HC, UITERKAMP AJ, NONHEBEL MS (2016) Problems with biogas implementation in developing countries from the persepective of labor requirements. Energies 9:1-16

35. WALEKHWA PN, MUGISHA, J. \& DRAKE L (2009) Biogas energy from family-sized digesters in Uganda: Critical factors and policy implications. Energy Policy 37:2754-2762

36. WAWA Al (2012) The Challenges of Promoting and Adopting Biogas Technology as Alternative Energy Source in Semi-Arid Areas of Tanzania: The Case of Kongwa and Bahi Districts of Dodoma Region. ["eprint_fieldopt_thesis_type_phd" not defined] thesis, The Open University of Tanzania.

\section{Figures}




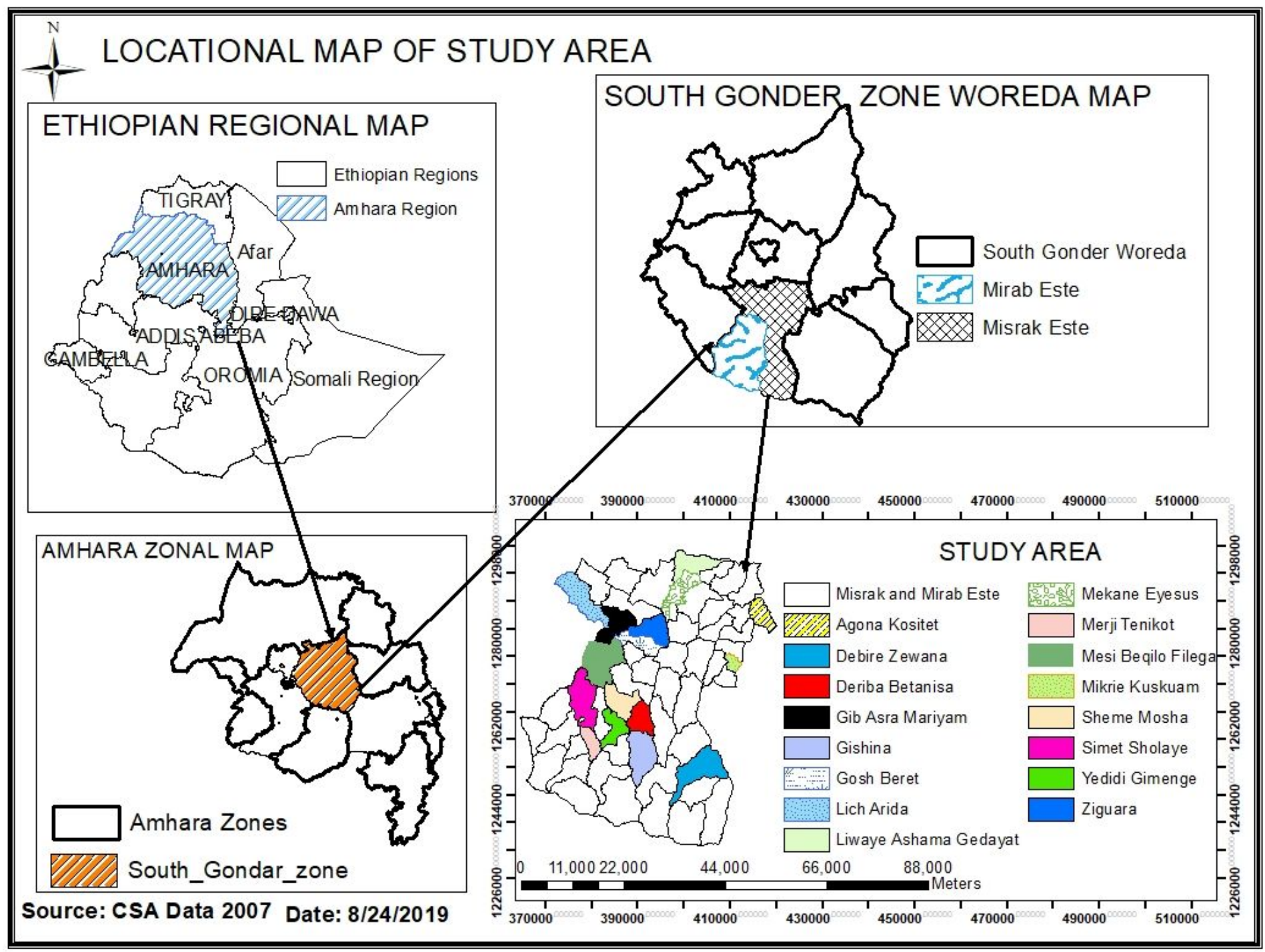

Figure 1

Physical map of study area Note: The designations employed and the presentation of the material on this map do not imply the expression of any opinion whatsoever on the part of Research Square concerning the legal status of any country, territory, city or area or of its authorities, or concerning the delimitation of its frontiers or boundaries. This map has been provided by the authors. 




Figure 2

Biomass and kerosene use pattern before installation of biogas plants 